\title{
Aprendendo línguas estrangeiras in-tandem: histórias de identidades
}

\author{
Maria Luisa Vassallo \\ Università Ca' Foscari de Veneza, Itália \\ Universidade Estadual Paulista, S.J. Rio Preto/SP, Brasil \\ João A. Telles \\ Universidade Estadual Paulista, Assis/SP, Brasil
}

\begin{abstract}
RESUMO: A Pesquisa Narrativa de Clandinin \& Connelly (2000) compreende a experiência humana como histórias vividas e contadas. Nesta abordagem qualitativa de pesquisa, os participantes contam histórias e os pesquisadores as recontam e as reconstroem por meio de narrativas acerca das experiências. Tendo este arcabouço metodológico como orientador de nossos procedimentos de pesquisa, neste artigo investigamos nossa experiência compartilhada de aprendizagem in-tandem do português e do italiano - no caso, uma experiência de oito meses por meio de um tandem face-a-face. Neste período, vivenciamos e coletamos dados acerca de nosso processo de aprender a língua um do outro: anotaçóes de campo, mensagens reflexivas de e-mail trocadas durante o período e o conteúdo anotado durante as aulas. Ao reviver nossas histórias vividas durante aquele período, por meio da narrativa aqui apresentada, ressaltamos os elementos de identidade no nosso tandem que acreditamos estarem relacionados à aprendizagem. Também individuamos os elementos desencadeadores de identidade específicos deste contexto de aprendizagem.
\end{abstract}

PALAVRAS-CHAVE: Pesquisa Narrativa, aprendizagem in-tandem, identidade, língua estrangeira, tandem face-a-face.

\section{Introdução}

Uma questão muito discutida no campo da Lingüística Aplicada há já uma década diz respeito ao binômio aprendizagem de língua/identidade. Tal questão é difícil de ser enfocada por causa da amplitude do conceito de identidade, que pertence a várias áreas diferentes e depende do viés adotado. ${ }^{1}$

\footnotetext{
${ }^{1}$ Por exemplo, o self pesquisado por meio da abordagem cognitiva na psicologia social, visto como uma rede de conhecimentos e de informaçôes organizadas, é diferente da identidade pesquisada pelas correntes que adotam a abordagem social, enfocadas nas relaçōes inter-indivíduos ou inter-grupos (MANCINI, 2001); esta última tem mais a ver com os conceitos adotados nas pesquisas da Lingüística Aplicada, geralmente atrelada a uma visão social da linguagem.
} 
Neste artigo abordamos o assunto em relação a um contexto de aprendizagem particular, a aprendizagem in-tandem, descrita no primeiro tópico, e por uma metodologia de pesquisa de cunho narrativo, que traz consigo um conceito específico de identidade - ambas apresentadas na segunda parte deste artigo. A terceira parte exporá nossas reflexões deflagradas por meio da pesquisa e nossas consideraçóes finais a respeito do que aprendemos.

\subsection{Aprendendo línguas estrangeiras in-tandem}

Tandem é o nome de uma forma de aprendizagem que se originou na década de sessenta na Europa e não era muito conhecida no Brasil até pouco tempo atrás. ${ }^{2}$ Consiste em um trabalho em pares, recíproco, autônomo e colaborativo; é realizado em sessões regulares bilíngües por falantes competentes de duas línguas diferentes que querem aprender cada um a língua do outro. As sessões de tandem são divididas em duas partes, dedicadas cada uma somente a uma língua. Nelas, os parceiros revezam-se nos papéis de aprendiz e de falante competente, dependendo da língua de competência de cada um. Cada parte da sessão geralmente dura pelo menos uma hora e pode chegar a duas ou mais. Dependendo da forma de tandem desenvolvida (VASSALLO, 2006), os parceiros são totalmente ou parcialmente livres de organizar as atividades que julgam oportuno desenvolver com o parceiro, geralmente associadas à oralidade.

Em comparação com outros contextos de ensino/aprendizagem, o Tandem possui características particulares. Em primeiro lugar, sua estrutura é dupla, implicando cada tandem o enfoque sobre duas línguas e culturas em igual plano de relevância. Isto impede que a língua materna do aprendiz, como facilmente pode acontecer em outros contextos, permaneça em segundo plano e que os participantes assumam uma postura unívoca, tendo que se revezar continuamente em dois papéis complementares - aquele de falante mais competente/nativo e aquele de falante menos competente. Em segundo lugar, o Tandem é um contexto informal, desenvolvido em forma de relacionamento

\footnotetext{
${ }^{2}$ Hoje, porém, está sendo desenvolvido no Brasil, por uma equipe de pesquisadores da Universidade Estadual Paulista (UNESP), o projeto Teletandem Brasil: Linguas Estrangeiras para Todos. Ver www.teletandembrasil.org . Este projeto experimenta o Teletandem, uma forma de Tandem a distância desenvolvida por meio do Instant Messaging e da video-telefonia pela Internet (VASSALLO; TELLES, 2006; ver, também, TELLES; VASSALLO, 2006).
} 
particular, entre duas pessoas, não acontece à frente de um público ou em situação formal-como poderia ser em sala de aula. Finalmente, o Tandem implica um duplo nível de atenção dos parceiros: interagindo, eles devem manter a atenção enfocada tanto sobre o conteúdo da interação quanto sobre a forma da língua usada, para poderem entrar em processos de colaboração.

Tais características levam a duas implicaçôes para as atividades colaborativas implícitas no Tandem: a relevância da relação entre os parceiros e o estímulo da reflexão acerca da língua e da cultura materna e acerca das formas de aprendizagem que emergem na relação entre os parceiros. No presente artigo, tentaremos mostrar que tais características e implicações são relevantes para a pesquisa sobre identidade e aprendizagem de línguas e que 0 Tandem fornece a nós, pesquisadores, um excelente contexto para o estudo das mesmas.

\subsection{Metodologia: a pesquisa narrativa de Clandinin e Connelly e as histórias que cada um escolhe para viver}

A Pesquisa Narrativa (CLANDININ; CONNELLY, 1995, 2000; CONNELLY; CLANDININ, 1988) que adotamos para realizar este estudo busca compreender a experiência como histórias vividas e contadas. Nesta modalidade qualitativa de pesquisa, os participantes contam histórias e os pesquisadores escrevem narrativas - relatos reflexivos, muitas vezes teoricamente orientados, acerca dessas histórias. As narrativas se constituem em modos de se compreender a experiência vivida dos participantes da pesquisa. Por meio delas, os pesquisadores lançam significados sobre aqueles que já foram dados pelos participantes. Para Clandinin \& Connelly (op. cit), “(...) histórias vividas pelas pessoas são experiências. As pessoas vivem histórias e, ao contá-las, reafirmam-nas, modificam-nas e produzem novas histórias" (CLANDININ; CONNELLY, 2000, p. xxvi). Ao estruturarmos nossas experiências de modo historiado (narrativo), educamos a nós mesmos; ao contá-las, educamos os outros. Do ponto de vista deste arcabouço metodológico inovador, a narrativa é, simultaneamente, fenômeno e método de estudo (p. 4).

Pesquisadores que trabalham com a Pesquisa Narrativa pensam de modo narrativo ao entrar em relações de pesquisa com seus participantes, produzindo textos de campo (p.92-118). Exemplos desses textos de campo (os dados - termo utilizado pela pesquisa tradicional) utilizados por pesquisadores narrativos são: anotações, histórias, autobiografias, diários, cartas (enviadas e não-enviadas), conversas gravadas em áudio, entrevistas, histórias de famílias 
e histórias sobre famílias. ${ }^{3}$ Mais abaixo, o leitor poderá perceber que, neste estudo, utilizamos uma mescla desses vários tipos de textos de campo, alguns com variaçóes, como por exemplo, mensagens de e-mail, ao invés de cartas enviadas, os quais foram rotineira e rigorosamente coletados. De acordo com Clandinin \& Connelly (2000), a composição de textos de campo (a) é parte do processo interpretativo; (b) expressa a relação entre o pesquisador e o participante (no caso deste estudo, fomos participantes e pesquisadores de nossa própria relação no contexto do tandem, estudando nossas prática) e (c) funciona em um espaço, chamado pelos autores de espaço tridimensional da pesquisa narrativa - temporalidade, espacialidade e o pessoal/social. Tal espaço permite que o pesquisador narrativo trabalhe "(...) dentro de um contexto de pesquisa tridimensional que é aberto e sem fronteiras: ao compor textos de campo, os pesquisadores necessitam estar conscientes do espaço no qual eles e seus participantes estão, em um determinado momento histórico, em termos do pessoal e do social. Finalmente, para esta modalidade qualitativa de pesquisa, é necessária a composição de vários tipos de textos de campo, pois estes se entrelaçam para a composição das narrativas.

Narrativas são relatos historiados a partir dos textos de campo - o que esses autores chamam de textos de pesquisa (p.119). A produção de uma narrativa (como o presente artigo) é, segundo Clandinin \& Connely (2000), uma transição desafiadora e pode se dar em meio à própria pesquisa (p.119). Nesta transposição de textos de campo para narrativas, um dos desafios do pesquisador ao produzir uma narrativa é justamente partir da dimensão pessoal da experiência vivida à dimensão social; caso contrário, a narrativa não passará de um movimento narcisista.

Para evitar tal limitação, é necessário dar constante atenção a tridimensionalidade da Pesquisa Narrativa. Por exemplo, as histórias que narraremos neste artigo estiveram situadas em um espaço (apontam para determinada situação), em determinada temporalidade (dentro de um determinado tempo - presente, passado e futuro) e transitaram entre as dimensões pessoal e social de nossas experiências vividas. Ao escrevermos o presente artigo narrativo (texto de pesquisa) acerca de nossas experiências de ensino/aprendizagem in-tandem, tivemos que aprender a pensar sobre elas de modo narrativo, prestando atenção às nossas vidas com as línguas estrangeiras (italiano e português) como vividas narrativamente e, também, de contextualizar nossa investigação dentro deste espaço tridimensional metafórico

${ }^{3}$ Em inglês: family stories, stories of families (CLANDININ; CONNELLY, 2000, p. 112) 
(p.120). Portanto, a narrativa aqui apresentada por meio deste artigo só terá o efeito esperado pela Pesquisa Narrativa se os seus efeitos forem entrelaçados com as histórias vividas pelos próprios leitores deste artigo. Somente assim o pessoal por nós vivido terá uma justificativa social, fazendo com que os leitores aprendam algo ao ouvir nossas histórias e produzam significados a partir de nossas experiências com a aprendizagem de línguas estrangeiras in-tandem.

Por fim, ao revermos nossos textos de campo produzidos enquanto tecíamos nossa história de ensino/aprendizagem in-tandem, a seguinte pergunta de pesquisa emergiu de nossas reflexões:

Qual a relação entre aprendizagem de línguas e identidade, concebida em termos narrativos conforme Clandinin \& Connelly, no específico tandem pesquisado?

\section{Um Tandem italiano-português}

O tandem pesquisado foi em italiano-português, presencial, profissional (ou seja, entre profissionais do mesmo setor), não institucional (ou seja, que não foi promovido ou realizado dentro de um contexto institucional, tal como uma escola de línguas ou uma faculdade) e não aconselhado (ou seja, os parceiros não se apoiaram, para o desenvolvimento do tandem, a uma mediação externa, sendo ambos profissionais do ensino, um dos quais já com experiências prévias de tandem). A duração do nosso processo de tandem foi de oito meses, sendo realizado pelos próprios autores deste artigo em uma cidade no interior do estado de São Paulo, em casas particulares, com sessões de cerca de quatro horas por semana.

De nós dois, João, falante nativo de português brasileiro e cidadão brasileiro, havia sido anteriormente professor de inglês e era docente universitário de Prática de Ensino; estava com 49 anos e já havia desenvolvido outros tandems, anteriormente. Luisa, falante nativa de italiano, havia sido na Itália professora de Latim, Grego e Italiano no ensino médio; vivia no Brasil há dois anos e meio e atuava como leitora junto à cátedra de italiano, na mesma universidade de João, onde deveria permanecer por quatro anos; estava com 46 anos. $\mathrm{Na}$ época na qual o tandem começou, a competência de João correspondia ao nível A1-A2 do Quadro Comum de referência europeu, ou seja, elementar; Luisa estava em um nível intermédio-avançado: aproximadamente B1 nas habilidades ativas (fala e na escrita) e $\mathrm{C} 1$ naquelas passivas (leitura e escuta).

Depois de algumas sessões iniciais de familiarização, o nosso trabalho comum organizou-se em torno de três pilares: 
(a) as sessôes presenciais, durante as quais desenvolvíamos uma conversação totalmente livre, dividida em duas partes dedicada cada uma a uma língua (a língua usada por primeira trocava, em razão do maior cansaço que percebia-se na segunda parte da aula). ${ }^{4}$

(b) as tarefas de casa, realizadas copiosamente porém irregularmente: geralmente textos enviados como anexos a um e-mail. 5

(c) E-mails quase diários, quase todos em italiano: inicialmente raros e estimulados por Luisa, por razôes didáticas e de pesquisa, tornaram-se em pouco tempo um meio habitual de comunicação entre nós. ${ }^{6}$

A documentação aqui considerada consiste em (a) tarefas de casa e anotações de cunho diarístico, desenvolvidas no período entre duas sessões; (b) e-mails trocados no período entre duas sessóes; (c) textos de pesquisa acerca desta experiência, escritos depois que o Tandem acabou e conforme a metodologia de pesquisa narrativa de Clandinin e Connelly (op. cit). Tais textos foram escritos em língua portuguesa (João), em língua italiana (Luisa) e em interlíngua português/italiano (João, Luisa).

As histórias aqui narradas foram tecidas com excertos de tais documentos. Entrelaçam-se três "camadas" narrativas:

- textos de pesquisa, escritos dezoito meses após o fim do tandem (código III, e em número reduzido), que compõem uma parte das histórias;

\footnotetext{
${ }^{4}$ Tal conversação era seguida geralmente de uma reflexão final sobre a forma (erros, regras a serem clarificadas, pontualizações lexicais, exercícios gramaticais etc), raramente muito longa ou aprofundada, que constituia a base para as tarefas de casa que eram totalmente livres, as quais, no acordo inicial, deviam constar em textos escritos relacionados de alguma forma com a sessão desenvolvida: resumos, sentenças que aplicassem regras apreendidas, etc.

${ }^{5}$ Tais textos eram compostos no caso de João com sentenças criadas expressamente para reutilizar o vocabulário e as regras apreendidas na sessão precedente, anotadas em papéis avulsos durante a sessão e depois reorganizados em um arquivo; no caso de Luisa, por textos mais compridos que inicialmente tentavam resumir o conteudo da conversação da sessão precedente, depois expressaram simplesmente reflexões sugeridas por acontecimentos ou questôes associadas de alguma forma com a sessão ou com o Tandem.

${ }^{6}$ A maioria dos e-mails é em italiano, a maioria dos anexos é em português. $\mathrm{O}$ volume impresso desses dados conta com cerca de 300 páginas.
} 
- textos de pesquisa produzidos nos dois meses logo após o tandem (código III, a maioria), que compõem a parte restante das histórias;

- trechos de textos dos e-mails e das tarefas de casa realizados durante o tandem (código I), citados nas histórias.

No texto, alternaremos a voz de João e aquela de Luisa, em textos de pesquisa separados. Em cada história aqui narrada, um de nós comenta excertos escritos por ambos; o autor de cada excerto é reconhecível pela inicial do código atribuído ao texto. ${ }^{7}$ Esta forma de proceder pretende ressaltar o tandem como um espaço de relacionamento e de co-construção de significados mantendo, ao mesmo tempo, a individualidade e a voz de cada um de nós. Uma reflexão final será oferecida na última parte desta narrativa.

\subsection{O português: rumo ao futuro. História de Luisa}

Italiana, professora de grego e latim, morava eu há muito tempo na mesma cidade do norte da Itália, Turim. Anos atrás, havia participado a um concurso do Ministério do Exterior da Itália, para ser leitora universitária no exterior, meio esquecido. Em uma manhã de inverno de janeiro de 2001, voltei para casa e enfiei a mão na minha caixa postal, retirando-a com um telegrama, completamente inesperado. O telegrama anunciava que seria enviada ao exterior como leitora, em um pais a ser escolhido.

Foi aquele um momento marcante da minha vida. Estava com 41 anos. Dali a sete meses estaria no Brasil, um país escolhido praticamente por acaso, onde não conhecia ninguém e cuja língua desconhecia, desenvolvendo um trabalho novo, longe de todas as minhas referências; estaria em uma casa e em uma cidade nova, sob uma arquitetura diferente, sob um sol que parecia alheio.

Seria, esta, a primeira vez que experimentaria uma mudança de trabalho e de vida tão grande - a primeira vez que viveria e trabalharia estavelmente em um país estrangeiro, uma experiência tão desejada por mim ao longo de toda minha vida e que foi tão difícil a se alcançar. Moraria e trabalharia no Brasil de 1 de agosto de 2001 a 31 de julho de 2005. Depois voltaria ao meu pais de origem e ao meu antigo trabalho, conforme previsto no contrato.

\footnotetext{
${ }^{7}$ No código do excerto e das próprias histórias, o autor é indicado pela sigla inicial do código (respectivamente $J$. e $L$ ), seguido pela categoria de texto (E-MAIL, TEXTO INTERIM, ANEXO, TEXTO NÂO ENVIADO etc.), pela indicação do período de composição (I, II, III, conforme acima explicado) e pela indicação específica do excerto (data do e-mail ou código numérico do texto ou do anexo etc.).
} 
Durante a moradia no Brasil, descobriria mais uma coisa nova, uma forma de se estudar línguas que não conhecia: o Tandem, que um colega, João, me convidou a praticar com ele, querendo trocar o seu conhecimento do português com o meu conhecimento do italiano.

Desenvolvi o tandem quando já falava já razoavelmente bem em português nos assuntos do dia-a-dia; podia ler alguns tipos de livros e jornais, entendia a lingua padrão. Minha vida profissional e afetiva desenvolvia-se com pessoas que conheciam ou aprendiam o italiano. Portanto, não estava muito motivada a aprofundar a lingua do país onde estava morando. Também, não precisava mais: dali a um ano e meio deveria deixar o pais, pelo vencimento do meu contrato. Apesar disso, aceitei fazer o Tandem por duas razóes principais: curiosidade e desejo de estimulos para melhorar meu português e para me apresentar, depois, para a prova de certificação do português para estrangeiros. $\mathrm{Na}$ realidade, acabei desenvolvendo reflexóes acerca da aprendizagem nos vários contextos e me interessando ao próprio Tandem como contexto de aprendizagem e à didática de forma mais geral; desta forma, o próprio Tandem indicou-me um caminho para o futuro, muito mais de que o simples fato de ter trabalhado e morado em um pais estrangeiro. (L. INTERIM III)

\subsection{O italiano: rumo ao passado. História de João}

Em uma tarde de 13 de outubro de 2003, no cartório local de Gambellara, Vicenza, província do Veneto, na Itália, onde nasceu meu avô materno, Silvio Maule, tornei-me, enfim, um cidadão italiano. O processo de obtenção da cidadania foi difícil e sofrido, em virtude da burocracia italiana, da pesquisa genealógica por mim feita com auxilio da irmã mais nova de minha mãe - tia Helena, e das várias vezes que foram necessárias viagens para tratar dos documentos.

A funcionária do cartório me deu a Carteira de Identidade AJ 5036619, em cujo verso estava escrito "Totale Diritti". Isso significa que posso gozar de todos os direitos como qualquer outro cidadão italiano nascido na Itália. Assim, mesmo após sua morte, naquele dia, minha mãe passava a herança da cidadania italiana a ela legada pelo seu pai, um imigrante italiano ao Brasil que desembarcou do vapor Washington, no Porto de Santos, em 29 de novembro de 1897, procedente de Gênova. Diferentemente de uma herança financeira, esta "herança cultural" só pode ser passada a mim, seu filho mais novo, porque nasci após 1948, ano em que a mulher italiana começou a transferir o direito da cidadania italiana aos seus filhos. Mesmo meu irmão, nascido em 1947 e minhas irmãs, com datas de nascimento anteriores a 1948, nunca poderiam ter conseguido a cidadania. 
Por razóes que, talvez, venha a expor nessas páginas, essa "herança cultural" chegou-me alterada. Alterada porque havia os direitos civis italianos, mas não tinha posse nem da lingua, nem da cultura italiana. ${ }^{8}$ Naquela tarde de outubro eu e minha mãe viríamos a "nascer simbolicamente" no cartório de Gambellara. Tornávamos, assim, cidadãos italianos, processo ignorado pelo meu avô e avó, os quais, talvez, nunca chegaram a pensar no desejo de sua filha e neto de se tornarem italianos.

Após ter conseguido o meu passaporte na Polícia Federal de Vicenza, ${ }^{9}$ eu caminhava em direção ao ponto de ônibus com o documento em minhas mãos. De vez em quanto, abria-o, talvez para verificar se aquela pessoa na fotografia era eu mesmo - um italiano-brasileiro, um brasileiro-italiano (a ordem dos fatores altera o produto, neste caso), com um primeiro nome muito português - João e um segundo nome talvez muito italiano - Antonio, expressão da identidade italiana de minha mãe sobre esse seu filho (devota de Santo Antonio di Padova, como minha avó materna paduana, ela desejou dar esta marca no seu filho mais novo, que quase chegou a perder, após uma gravidez dificilima). Abria o passaporte tentando verificar qualquer marca de italianidade em meu nome. Nem mesmo um nome ou sobrenome italiano (carrego o sobrenome Telles de meu pai, mas não o italiano Maule de minha mãe). Como local de nascimento, $o$ passaporte diz: "Luogo di Nascita: Jundiai S.P., (BRA)". Por herança, a Itália era também minha, como de qualquer pessoa italiana que por mim passava nas ruas. A Itália havia se tornado o meu país. Sentia-me privilegiado por ser cidadão de doispaises.

Por que tanto empenho em se conseguir uma cidadania italiana aos 49 anos de idade? Com certeza, nesta idade, é difícil mudar de país e de um posto de trabalho. Minha vida, minha profissão, minha lingua materna estavam no Brasil. Era cidadão de um país que mais me parecia um país estrangeiro. Não tinha intenção de me mudar para a Itália e lá viver.

${ }^{8}$ Por "herança cultural" quero dizer não somente a lingua italiana, mas também o conhecimento acerca da cultura (aquilo que é produzido pelos italianos) e a competência cultural para agir e interagir social e politicamente dentre aqueles que são designados como italianos. Achava que não conhecia nada da Itália, a não ser os esteriótipos comuns. Contudo, conforme se verá no decorrer desta narrativa, alguns legados culturais, comportamentais, gastronômicos e lingüisticos foram, sim, deixados em minha memória pela minha mãe, meus tios e tias (os nascidos e não nascidos na Itália).

${ }^{9}$ Questura di Vicenza. 
Certo dia, em uma conversa, ouvi um brasileiro com cidadania portuguesa exclamar: "Para que serve um passaporte português, a não ser para entrar na Europa sem passar pela fila de estrangeiros na imigração portuguesa?”. Minha relação com a Itália não é assim. Além dos documentos a mim outorgados pela lei de descendência, decidi aprender a lingua italiana e me tornar "culturalmente competente" em relação à Itália - não seria a mesma língua dos meus avós, que falavam o veneto, mas seria a língua da Itália. Foi assim que entrei de acordo com Luisa para compartilharmos aulas de linguas in-tandem face-a-face e deixar de ser um "italiano de araque", que só tem os documentos italianos, mas não fala e não entende nada da Itália. Uma cidadania de um país não significa somente passar mais rápido na fila de imigraçāo no aeroporto: é muito mais que isso, como tentarei demonstrar por esta narrativa a respeito de um processo de aprendizagem de linguas in-tandem - o qual, na verdade, transcendeu um simples processo de aprendizagem de linguas para se tornar um processo de "aprendizagem cultural in-tandem". (J. INTERIM II)

\subsection{Tandem, para quê? $O$ português, não preciso. História de Luisa}

Minha perspectiva acerca do tandem foi diferente daquela de João. Eu não tinha motivaçóes, para a aprendizagem da minha lingua-alvo, o português, relacionadas com uma herança cultural e familiar: no meu caso foi o próprio tandem a criar elementos afetivos e familiares acerca da língua, e não vice-versa. Em segundo lugar, diferentemente do meu parceiro, morava no pais da minha lingua-alvo; finalmente, nunca tinha feito um tandem antes. Portanto, $o$ papel que assumimos um aos olhos do outro não foram homólogos. (L.INTERIM III)

Não acredito ter assumido, diante do tandem, uma atitude diferente de outras coisas que faço na minha vida. Aceitando fazê-lo, queria simplesmente saber ao que levaria. Havia uma motivação instrumental (o exame de certificação), que porém, em si, não podia ser suficiente. João foi inicialmente o elemento ativo do nosso tandem, a pessoa que tinha experiência e que propunha um esquema de trabalho. Para mim, a proposta foi inicialmente só uma oferta extravagante que recusei (naquela época não havia nem tempo nem disponibilidade), depois a fonte de um leve sentido de culpa (eu tinha dito não a uma pessoa querendo aprender, um dos maiores pecados para a minha ética), finalmente algo a se aceitar porque me deixava curiosa - por entrar nos novos esquemas que, no entretanto, havia construido para mim, como professora de lingua estrangeira e aluna de mestrado em Ensino de Linguas. 
Pouco após ${ }^{10}$ começarmos o tandem, meu companheiro de trabalho se preocupou com a idéia de que o Tandem não fosse útil para mim, pelo desequilíbrio de proficiência entre nós. Refletindo sobre minhas motivaçôes, the enviei uma lista de objetivos:

- aprender algo novo acerca dos mecanismos e das técnicas de ensino/ aprendizagem

- conhecer uma pessoa nova aqui no Brasil, com a qual fazer, em fim, algo concreto

- treinar em português, porque sou terrivelmente preguiçosa e nunca estou com vontade de fazê-lo

- desde o momento no qual descobri que você é professor de didática, aprender tudo o que posso aprender de você neste assunto

- desde quando você me chamou atenção para o fato de que existem também o acento e a entoação, melhorar minha pronúncia (L. EMAIL, I: 01/05/2004).

Não é casual o fato de que a aprendizagem da língua, aqui, só esteja em terceira e em quinta posição. Na realidade, um outro elemento começou a prevalecer desde o começo, quando me dei conta de que estava na frente de uma pessoa que para mim era uma espécie de reservatório de dados e informaçôes que me interessavam enormemente. Sempre tive a tendência a considerar as pessoas como enciclopédias e quase a querer folheá-las e lê-las a qualquer custo; mas naquele caso o impulso era ainda mais forte, porque acompanhava meus interesses no momento. Por causa do meu novo trabalho, de fato, acabava de descobrir a didática.

No primeiro lugar da lista, de fato, está a aprendizagem acerca da aprendizagem. Isto mostra o segundo e mais específico elemento do nosso tandem: foi também um metatandem. Dois professores de lingua estrangeira têm interagido para aprender um a lingua do outro, discutindo constantemente (naquela mesma língua) sobre o que estava acontecendo e o porquê. Não foi o único assunto, mas a aprendizagem e o próprio tandem têm sido, desde o começo, um dos temas chave. Evidentemente, para meu parceiro de tandem não se tratava de assuntos novos; no entanto, para mim, uma parte do fascinio daquelas conversas infinitas, que duravam a tarde toda, estava exatamente na possibilidade, em fim, pela primeira vez, de ter alguém com quem falar face a face destes assuntos.

${ }^{10}$ Por volta de dois meses depois. 
Na segunda posição da lista aparecem a interação pessoal (conhecer uma pessoa...) e, ao mesmo tempo, a necessidadeldesejo de "fazer algo" no pais da lingua alvo. Este último aspecto é a segunda previsivel motivação de um tandem: o estudo da língua como meio de se relacionar com maior eficácia com as pessoas e a cultura da língua alvo.(L.INTERIM, II) e foi compartilhado por ambos nós, ${ }^{11}$ representando uma ligação entre nós.

\subsection{Dê-me a sua mão que mostrarei o que é a Itália. História de João}

Desde o primeiro mês de Tandem já era claro o meu interesse de construção de uma identidade italiana - identidade aqui vista, nos termos de Connelly \& Clandinin (1988), como "histórias que alguém escolhe para viver". Assim, optei por viver a história de um italiano, filho de mãe italo-brasileira e neto de avós italianos. Meu tandem com Luisa proporcionou o contexto para organizar os "instrumentos para viver a história de um brasileiro que se torna italiano por herança". Esses "instrumentos" são por mim vistos no presente momento como: (a) a lingua italiana, (b) o conhecimento da história e da geografia da Itália e (c) a competência cultural para compreender e agir segundo os costumes e hábitos italianos quando estiver em interação com os nativos desta cultura.

Pelo tandem, aprendia italiano e buscava organizar em minha mente as histórias herdadas pela minha mãe e sua familia. Neste processo, havia as histórias de minha mãe e avós italianos (as quais não eram as minhas histórias, mas haviam sido passadas por intermédio de minha mãe). Se para isso, precisei organizar não somente as histórias e os documentos do passado para a obtenção da cidadania italiana, comecei junto às sessóes do tandem, a viver as minhas próprias histórias com os italianos, com a ajuda de Luisa. Esta não me pareceu consciente desta ajuda, embora na maioria das vezes estivesse pronta não só para me fornecer informaçôes sobre a sua língua, mas também informaçôes pertinentes à cultura e aos hábitos italianos. Enquanto Luisa enfocava sua atenção sobre o contexto de aprendizagem in-tandem, no qual estava interessada, pelo seu próprio comportamento ajudava-me na organização das informaçôes por meio de nossas conversas e mensagens de e-mail (essas últimas nos ajudam, agora, a obter as informaçôes sobre o processo do tandem, porque foram registradas de forma escrita). $\mathrm{Na}$ mensagem de 12 de março de 2004, abaixo, Luisa ilustra o clima de nossas

${ }^{11}$ Ver, abaixo, a seção 2.8 , acerca do viés etnográfico do nosso tandem. 
conversas, seu interesse pelo método do tandem, organiza e questiona as informaçôes que trouxe para o tandem a respeito de aprendizagem.

(...) Gostei de sua maneira tranqüila de conduzir a conversação, e fiquei convencida de que esse método Tandem (ou pelo menos a versão que você está desenvolviendo [desenvolvendo]) é um bom método e pode ser útil para mim também, tanto do ponto de vista professional como tambem do ponto de vista lingüístico.

Achei interessante tudo o que você falou sobre o seu relacionamento com Itália, sobre italianos aqui no Brasil e lá na Itália, sobre o fato de o Marcelo ser muito mais italiano de que você (asunto [assunto] que eu gostaria de poder entender melhor, se um dia você tiver vontade de retomar), sobre essa sua inabalável convicção do que a forma de ensino do professor é totalmente sócio-construida (asunto também sobre [o qual] que pretendo aprender mais de você, mesmo que não esteja muito convencida, pelo menos no tocante ao próprio aspecto psicológico, como já tentei lhe explicar)... (L.E-MAIL I: 12/03/2004)

Minha resposta a este e-mail de Luisa vem carregada de informaçôes sobre o processo de aprendizagem que estávamos iniciando e minha determinação de, tendo Luisa como mediadora, construir uma identidade italiana por meio de minhas próprias histórias e não as de minha mãe ou avós. Assim, Luisa passa a significar, para mim, a Itália de hoje, a Itália de pessoas da minha idade, com as quais desejo travar relaçôes por livre escolha e não relaçôes herdadas, como as de uma familia. Assim descrevo o que sentia no inicio do Tandem, em minha resposta, em italiano, por e-mail (notar os erros que cometia): ${ }^{12}$

Anche a me, [la]nostra conversazione en [in] italiano, tanto quanto en Portoghese, mi è piaciuto [piaciuta] molto Tu sei la prima persona italiana con cui ho potuto parlare en italiano ed avere un cambio [uno scambio] d'idee ed esperienze interessanti. Magari perché prima d'esse[re] tornato a [in] Brasile da[lla] Francia, ho parlato soltanto con i miei parenti italiani con cui non ho tanti [tante] cose en comune. Magari, dopo d'avere te conosciuto [dopo averti conosciuto], potrei trovare persone italiane chi m'interessa [che mi interessano]. Questi sistemi di relazione sociale sanno [sono] molto importanti per continuare a costruire la

\footnotetext{
${ }^{12}$ Todas essas mensagens de e-mail são escritas sem muita atenção à gramática ou vocabulário, com a intenção primeira de comunicação. Lembro-me que essas mensagens levavam muito tempo para serem escritas, com auxílio de dicionário.
} 
mia relazione con [l'] Itália con gli italiani, MI piace [piacciono] la lingua, l'arte e la cultura italiana. Adesso voglio conoscere le genti [persone] italiane con cui posso avere [un] dialogo. (J. E-MAIL $I^{13}$

Tínhamos um conhecido em comum, $N$., nascido no Brasil e filho de pais italianos. Em um dos nossos encontros, citei N. como sendo "mais italiano que eu", não somente por poder ter a cidadania italiana, mas também por poder falar a lingua italiana e conhecer detalhes acerca da Itália. No excerto do mesmo e-mail, abaixo, trato dessas questôes:

Ti affermava che N. è più italiano di me perché lui può parlare italiano, lui ha un nome italiano, lui se assomiglia ad un italiano (suo comportamento, per esempio). Mia madre ed i sui fratelli e sorelle hanno occultato quest'italianitá. In ogni caso, non la hanno dimenticato, contuttoché non la hanno svillupato fra i suoi figli. Ti spiego poi, magari perché mio nono voleva dimenticare Italia quando è venuto qua per la seconda volta e rimasto tutto il resto de la sua vita con i suoi figli e moglie. Molto interessanti queste cose chi ti racconto. Conforme scrivo, faccio una riflessione e tento costruire un'identitá la mia propria, come un nuovo italiano. Ci sanno studi antropologici sull'identitá étnica chi sostengono che la lingua è il primo requisito del sentimento de nazionalità, de s'appartenere a un gruppo sociale. (J.E-MAIL I: 12/03/2004)

Já no início do Tandem, afirmo que a lingua é um requisito primordial para se sentir como possuidor de uma cidadania. É certo que cidadania não é simplesmente isso e que ela se constrói mediante a ação do indivíduo na sociedade na qual está inserido. O fato é que iniciei a construção de minha identidade italiana quase a partir de um procedimento arqueológico. Busquei as histórias, em seguida os documentos (certidóes de nascimento de meus avós italianos, por exemplo), corrigi os nomes desses documentos que continham nomes completamente incorretos; enfim, foi como se meus avós e mãe houvessem perdido tudo aquilo que era italiano, como se um vendaval houvesse passado e levado toda a "italianidade concreta" (documentos, histórias e informaçôes sobre a Itália). Digo italianidade concreta porque os traços da "italianidade subjetiva" permaneceram em minha mãe (comida, certos comportamentos e uns "cacos" da lingua falada no Veneto, os quais minha mäe usava quando brincava ou quando se irritava).

${ }^{13}$ Editamos aqui somente o primeiro dos textos em interlíngua, respectivamente em italiano e em português, indicando entre parênteses a forma correta. 
Uma vez conseguidas as "provas da cidadania italiana" - a carteira de identidade e o passaporte, inicio com o Tandem minha procura de outros atributos desta identidade italiana. Nosso conhecido, $N$., faz-me um ponto de referência-seus documentos italianos sempre estiveram corretos e presentes, falava a lingua com soltura, possui nome e sobrenome italianos. Meus documentos italianos não contêm nenhum nome italiano, porque não herdei o nome de familia de minha mãe. O que tenho de "mais italiano" é o meu segundo nome - Antonio, o qual nem mesmo chega a ser completamente italiano, já que é um nome tão comum em espanhol ou português, por exemplo. (J. INTERIMII)

\subsection{Dê-me a sua mão que Ihe mostrarei o que é pesquisa. História de Luisa}

Desde o começo, o Tandem com João representou para mim também uma inusitada forma de atualizaçâo profissional: sendo João professor de didática, para mim ele era uma pessoa qualificada com a qual conversar de ensino e de aprendizagem, como não podia mais fazer depois de ter acabado um curso de didática. Por um lado, o fim das aulas tinha me deixado sem parceiros com os quais discutir; por outro lado, eu ainda estava muito nova nestes assuntos e meus conhecimentos não eram profundos como eu desejava. Encarei, portanto, o Tandem com João como uma ocasiāo para aprimorar minha reflexão acerca do ensinolaprendizagem, olhando para este novo contexto e para a aprendizagem do meu parceiro de maneira profissional. Minha reflexão, progressivamente compartilhada com João, foi levada a cabo em português e em italiano, e andou junto com o meu esforço para me apresentar, aos olhos do meu parceiro, como competente em questôes de lingüistica aplicada e me afirmar como profissional do ensino.

Este esforço chegou a ser, para mim, quase uma luta silenciosa, para convencer meu parceiro a discutir estes assuntos comigo. Por um lado, levou-me a solicitar tarefas de casa acerca de assuntos relacionados com a sua profissão, como pode se ver no meu e-mail, abaixo (os pronomes são em negrito no original, porque estávamos trabalhando sobre os pronomes):

Ciao. finché siamo in vacanza ne approfitto per chiederti delle cose.

Allora, la mia prima richiesta è questa: per favore, per mia utilità personale tesistica, potresti scrivermi che cosa nel mio atteggiamento durante il Tandem ti fa imparare di più (grammatica-lessico), o per lo meno che cosa trovi caratteristico del mio comportamento? Non teorie, ma solo quello che succede a te, Joãonescamente, a seconda di come mi comporto io, Luisianamente (io non so come mi comporto, non me ne 
accorgo. Questo è il problema... tu per lo meno hai dei termini di confronto, con tutti i tandem che hai fatto!). Accettiamo contributi in qualsiasi lingua, da 5 righe a 50 pagine, non è necessario premettere curriculum

Grazie $\mathrm{n}^{\circ} 1$.

In cambio, ti mando il segreto del proverbio dell'asino (...)(L. EMAIL I: $29 / 5 / 200)$

Por outro lado, o esforço de afirmar minha identidade desejada (Markus \& Wurf, 1987, apud Mancini, 202:33.) levou-me também a escrever de assuntos técnicos em português, muito além das competências lingüisticas que possuía, para ter a certeza que meu parceiro lesse os meus textos; meu objetivo era que os comentasse, desta forma me ajudando, com sua experiência e seus conhecimentos, a enfocar melhor os assuntos tratados. Para tanto, eu precisava dos termos técnicos exatos, equivalentes aqueles que já possuía em italiano, e o medo de que meu parceiro avaliasse minha competência profissional assimilando-a à minha competência lingüistica me impulsionou a estudar e aprender. Até aqui, o processo foi em grande parte ciente.

Várias vezes tive a sensação de que o meu desejo de ser levada a sério do ponto de vista profissional e como pesquisadora iniciante, aliás nunca explicitado, não fosse percebido pelo meu parceiro. Após o final do Tandem, descrevi este aspecto nos termos seguintes:

João chegou a fazer este Tandem mostrando ter uma idéia de mim que não correspondia à minha auto-imagem. Por exemplo, ele sempre traduzia com polidez e com solicitude cada termo inglês que dizia; nem me perguntou se eu conhecia o inglês, como se desse por subentendido que eu não o saberia. ${ }^{14}$ Isso me INFASTIDÍ [me amolava] muito, desde o primeiro encontro, porque achava que esta atitude, embora oficialmente em acordo com as regras de polidez e de etiqueta, implicasse também uma ligeira matiz de condescendência e de subestima, que eu não podia aceitar, apesar de não ser, efetivamente, professora universitária como ele. Estes subentendidos pertencem exclusivamente a mim, porque tenho certeza de que nunca, conscientemente, meu parceiro de pesquisa pensou nessas questóes. A mesma atitude ele mostrou nos assuntos de educação; apesar de eu

\footnotetext{
${ }^{14}$ Este é também um traço da sua identidade, pois ele, em passado de professor de inglês, associa uma parte da sua identidade a esta língua, que aprendeu como L2, em um ano passado nos Estados Unidos, quando adolescente. Aqui também se vê o jogo da negociação de identidade que aconteceu entre nós.
} 
acabar de participar às aulas de um mestrado bienal em didática, muitos meus comentários acerca de questôes de ensino eram ingênuos, como eu mesma me lembro. Mas, pelo outro lado, ele parecia agir como se eu fosse no mesmo nível dos seus alunos, nestes assuntos, por costume de professor ou por convicção.

Para salvaguardar a minha auto-estima, eu não podia aceitar que, no jogo da negociação de identidade entre nós, ele impusesse uma versão de mim tão "inferior" à que eu levava comigo (...). Portanto, desde o segundo encontro, quando ele se pôs, professoralmente e com muita boa vontade, a me explicar o conceito, básico para um profissional, de competência comunicativa, que eu já conhecia, (...) eu não disse nada. Porém, em algumas mensagens que lhe enviei depois, mais instintivamente do que cientemente, coloquei algumas referências para deixar claro que aqueles assuntos e aqueles termos técnicos não estavam totalmente desconhecidos para mim. (L.INTERIM $I I, \ldots$. )

Um exemplo da atitude mencionada pode ser visto no meu uso de termos técnicos neste excerto, tirado de uma das primeiras tarefas de casa que enviei ao meu parceiro:

Nem me lembro direito do que falamos, só sei que a conversa vagou de um assunto para outro sem se fixar em nenhum, mas lembrome bem da sua expressão assustada quando lhe pareceu que eu não tivesse a menor idéia de o que é aquela ferramenta fundamental chamada de competência comunicativa... (minha ênfase). Não se preocupe, João, você não está nas mãos de uma louca que nem sabe quando é o momento certo de usar o registro formal e quando não. Juro que não vou ensinar-lhe a usar egli no lugar de lui, ció em vez de questo - no sentido de isso - e coisa parecida. Sempre que tiver implicações socio-pragma-estratégicas na escolha de uma palavra prometo avisar você...

Falo sério, já que o italiano também tem esse problema de uma grande variação entre a língua falada e escrita, variação esta muito maior do que aquela encontrada em outras língua européias, devido à sua origem e à sua longa tradição exclusivamente literária. Acho que tenho alguma sensibilidade, como italiana, às implicaçōes da escolha de uma forma culta em um contexto informal. Mas também pode ser que a situação que eu acho parecida não seja bem assim e espero que você me ajude a entender as diferenças. (L.ANEXOI, 1, 18/3/04)

Seria exagerado dizer que todos os inúmeros emails e anexos que enviei durante o Tandem, respondiam ao único objetivo, porém vital para mim, de 
reconfirmar e re-estabelecer, diante do meu parceiro, uma identidade ameaçada; contudo, pode-se dizer que no nosso Tandem este aspecto existiu:

Inoltre io voglio disperatamente sentirmi una che studia, e per questo la professione di João per me è importante. Non solo per le conoscenze che mi può dare (nomi, libri, concetti), ma perchè accettando di parlare con me" alla pari" e di parlarmi del suo lavoro (e poi di coinvolgermici) mi legittima. (L.TEXTO NÃO ENVIADO $I$, "PALAVRAS CHAVE")

Ao longo deste processo todo, enquanto minha imagem do meu parceiro de Tandem ia se transformando cada vez mais naquela de um companheiro de discussão também profissional, percebi que meus esforços estavam tendo algum resultado e que minha imagem aos seus olhos estava mudando:

Cara Luisa,

Fra la traduzione pesante che faccio ed alcuni momenti di pause, ho letto la tua belissima riflessione sul Tandem e ho trovato che tu hai tremendamente si aprofundato al compito di refletire sul nostro processo d'aprendimento. Devo te rispondere presto, perchè ho trovato alcune ponti con cui non sono d'accordo. Per validare nostri interpretazzioni dobbiamo parlare con gli altri spesso. I miei risposti saranno un modo di validare quelli interpretazioni che tu hai fatto. (minha ênfase)

Non posso credere che scrivo prestissimo questo messagio. Due mesi fa, io non potevo scrive niente in italiano si non visse il dicionario. Ogni modo, ho avuto contato con questa lingua tutti i giorni, perchè leggo i tuoi messagie ed anche le cose che tu scrivi ed gli articoli che trovo en quello sito del internet. L'italiano entra en la mia testa dolcemente ed comincio a sentire una certa familiarità, si bene che ancora faccio tanti sbagli. Ti ringrazio la conversazione d'ieri ed anche i tuoi analise del tandem. (minha ênfase) Auguri! João (J.EMAIL $I, 15 / 5 / 04)$

Por este e-mail, assim como em vários momentos das sessões, comecei a me sentir reconhecida por ele como profissional. Alguns meses depois, finalmente, no periodo final do Tandem, o próprio João, ao perguntar qual era a metodologia de pesquisa da tese de mestrado que estava escrevendo, daria um reconhecimento ainda mas claro e chegaria a ironizar sobre meus problemas de auto-afirmação acima citados, um sinal talvez de que estavam resolvidos para mim, tanto que era possivel brincar a respeito: 
Luisa, cara mia,

I tuoi comentari sul quello che ho scritto sono molti interessanti. Sei davvero interessata sugli aspetti culturali della comunicazione in lingue stranieri (per quello che hai comentato). La metodologia di ricerca che usi nella tua tese è la Ricerca Etnografica? (minha ênfase) Dopo il "evento sulla competenzia comunicativa", non oso ti chiedere più si tu avrei letto Gumperz sulla "descrizione profonda" oppure Cazden. (minha ênfase)

Ti mando allegata una presentazione mia sulla ricerca etnografica in Power Point (con base/fondatto in Donna M. Johnson "Approaches to Research in Second Language Learning, 1992). (J. EMAIL I: 9/9/2004)

Desta forma, graças também ao complexo jogo de identidades realizado, o meu português escrito e o italiano de João deslancharam. ${ }^{15}$

Houve, portanto, uma mistura, dentro do Tandem, entre troca lingüistica e acadêmica, entre conotaçôes de identidade associadas à nacionalidade e à profissão.

\subsection{Vestir as roupas de um personagem. Tandem como jogo teatral. História de João}

Todas minhas experiências contribuíram para que eu construísse uma visão de aprendizagem de línguas estrangeiras como um complexo e divertido jogo, um teatro no qual, pouco a pouco, durante o processo de aquisição,

\footnotetext{
${ }^{15} \mathrm{O}$ próprio João, nos seus textos reflexivos, escritos após o final do Tandem, comentando a origem da nossa pesquisa escreve:

A idéia de nos observarmos como aprendizes de língua estrangeira no contexto do Tandem surgiu logo no início de meu processo com Luisa. Seu principal interesse se concentrou nos procedimentos pedagógicos de nossa experiência de Tandem, enquanto que, para ela, a aprendizagem da língua portuguesa ocupou um interesse secundário. Quanto a mim, concentrei meus esforços na aprendizagem da língua italiana e, aos poucos e em virtude da motivação de Luisa para observar a pedagogia do Tandem (e também de sua curiosidade e capacidade de observação), comecei a interessar-me pelo que fazíamos durante as quatro ou cinco horas que nos encontrávamos todas as sextas-feiras à tarde. Como alunos/professores e também como dois pesquisadores de prática de ensino de língua estrangeira, (minha ênfase) nossos conhecimentos acerca de metodologias de pesquisa na área de Aquisição de Línguas Estrangeiras e Lingüística Aplicada, começamos a pensar nas formas de registro da experiência do Tandem enquanto desenvolvíamos os nossos respectivos aprendizados (...) (J.INTERIM $I$ )
} 
brincamos de vestir as roupas de um personagem para que, por alguns momentos, possamos agir "na pele" (e, por que não, na língua) do mesmo. Luisa parece compartilhar comigo esta minha analogia de aprender uma língua estrangeira com o vestir a roupa de outro personagem em uma de suas mensagens de e-mail:

Uma pessoa fica quase nua, emocionalmente (e socialmente?), ao falar uma língua estrangeira que não conheça perfeitamente. (minha ênfase) Disso todo mundo sabe, e não é por acaso que tantos adultos se recusam a falar em um outro idioma, mesmo quando poderiam. [L.EMAIL I: 08/05/2004]

Para jogar este jogo, logicamente, requer-se boas doses de afetividade e de admiração pela nova língua e cultura e vontade de usar esta "nova roupa". Afetividade e admiração para com os outros personagens que o complementam (os falantes da língua-alvo) e para com o contexto onde eles atuam (o pais onde a língua-alvo é falada). Freqüentemente, é possivel gostar tanto deste novo personagem que, ao invés de interpretá-lo, passamos a vivê-lo, como se fosse nosso segundo, terceiro ou quarto heterônimo. ${ }^{16}$ Acredito que, o grau, profundidade e seriedade com os quais optamos jogar este jogo está correlacionado com o nivel de proficiência que atingimos na língua estrangeira. A mudança de voz (alemão soa na garganta, japonês soa na região dos seios da face, francês soa no bico da boca, etc.), da entonação, a maneira de se articular as novas palavras na língua-alvo são todos detalhes pelos quais optamos para compor este novo heterônimo-uma espécie de novo selfou segunda personalidade.

Aos escrever essas linhas, começo a imaginar os sentidos simbólicos que a aquisição de uma cidadania italiana deve ter tido para que eu iniciasse o meu aprendizado da lingua italiana para montar o heterônimo Giovanni Antonio e

\footnotetext{
${ }^{16}$ Segundo o Dicionário Aurélio, "Outro nome, imaginário, que um homem de letras empresta a certas obras suas, atribuindo a esse autor por ele criado qualidades $e$ tendências literárias próprias, individuais, diferentes das do criador. (...) Na última acepção, a palavra parece haver começado a circular após o surgimento de Fernando Pessoa (1888-1935), grande poeta português, que, além de usar o próprio nome em diversas produções, muitas assinou com os nomes Álvaro de Campos, Alberto Caeiro, Ricardo Reis, e outros, poetas, cada um destes, de características bem individuais, tanto nos meios expressivos quanto na substância, e até com biografias, curiosamente inventadas por Fernando Pessoa" [minha ênfase].
} 
encontrasse, em Luisa, a mediação de um coach para auxiliar-me neste trabalho ${ }^{17}$ - mais do que interpretá-lo, desejei viver o "personagem italiano" pois, agora, ele teria passaporte e carteira de identidade; isto é teria potencial para adquirir vida no "mundo real".

O tandem com Luisa começa, assim, como um jogo lúdico de acordos e regras compartilhadas no qual aprendo o italiano não somente para conhecer uma nova lingua e uma nova cultura, mas também para compor um possivel heterônimo italiano. Ao escrever essas linhas, recordo-me de algumas mensagens de Luisa e vejo que minha parceira de Tandem também se diverte com um semelhante "jogo de composição de personagem"-por exemplo, sua "versão brasileira":

para mim também é melhor às cinco da tarde, de fato eu ligaria hoje para propôr. Sorvete também é ótimo!

No caso de você não ler essa mensagem, ligarei por volta de dêz horas para confirmar

Tchauzinho

Luiza con Z (versão brasileira) [L.E-MAIL I: 25/04/2004] (minha ênfase)

E eu, aceito jogar o mesmo jogo, pois o mesmo só pode se configurar como tal quando são compartilhados, com o intuito de adquirir um status de "verdade por acordo mútuo":

Buon giorno Luiza (verzione brasilianna), (minha ênfase)

Grazie per il dolce che hai me datto. Delizioso, principalmente con caffe.

Ho fatto frasi con tutto il vocabolario che ho imparato nel venerdi. Vedi si stà correto, per gentilezza.

No vediamo nel venerdi. Grazie,

João (J.E-MAIL $l$ )

Há, também, outros jogos de identidade nos quais adquiro vários nomes dados por Luisa. Por exemplo (minha ênfase):

Caro Giovanni-Zuan,

sì, è stato proprio un pomeriggio o piacevole [L. E-MAIL I: 09/05/ 2004]

\footnotetext{
${ }^{17}$ Por vezes, Luisa adquiriu um papel de "treinadora" (coach), procurando os recursos apropriados para ajudar-me a construir esse novo personagem. Em um e-mail Luisa diz: "Ho visto che io mi sono concentrata di più sul pescare delle risorse utili per la tua conoscenza dellitalia (...)"(minha ênfase) [L.E-MAIL I: 01/05/2004]
} 
Ciao Antonio-cara-de-pau! Mi rallegra vederti al lavoro. [L. E-MAIL: $10 / 07 / 2004]$

\section{Caro Antonio,}

ho riscritto il messaggio con tutte le cosine al loro posto (doppie, pronomi eccetera). [L. E-MAIL I: 03/07/2004]

E Luisa, por sua vez, veste as roupas de outros personagens, desta vez, não tão ligados à questão de nacionalidade, mas aos momentos pelos quais passou durante o Tandem, tais como na época que havia sido operada e sentia seu corpo muito fraco (a velhinha - la nonnina), ou ao seu "estado de espirito de cigana" quando comprou um vestido para uma cerimônia de casamento que mais se adequava a um personagem de "cigana". É interessante o seu uso de imagens animadas para compor esses personagens temporários:

De novo obrigada pela bela tarde de ontem

Pode corrigir esse texto, se quiser

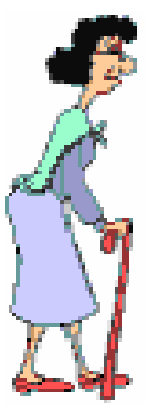

la nonnina

(L.E-MAIL.I)

Puoi correggere quello che ho scritto, per favore? Grazie - è piacevole scriverti.

Ciao

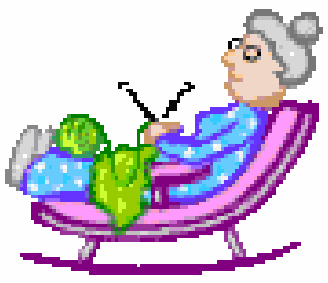

[L.E-MAIL I: 10/09/2004] 
NON devi fare il plurale di film, è un errore socialmente connotato. Solo gli ignorantoni dicono "filmi"... e noi non vogliamo essere ignorantoni, vero?

Buona notte

Luisacigana (aah, il mio meraviglioso vestito!!!! Se insistete molto, domenica posso farvelo vedere.... ;-) [L.E-MAIL $I: 16 / 09 / 2004$ ]

O jogo parece ter sido levado à frente de maneira implícita. Somente no momento de refletirmos sobre os resultados e o processo do Tandem é que as intençôes e os acordos vêem à tona. De certa forma, eu e Luisa parecemos ter compreendido os movimentos deste jogo de identidades conforme se desenvolvia o processo e enquanto trocávamos mensagens de e-mail com nossas reflexóes. Em uma delas, demonstrando uma capacidade de reflexão muito forte, Luisa explicita nossa dinâmica de relaçôes durante o jogo de identidades (nesta mensagem, é possivel notar, também, as reflexões e dúvidas de Luisa no exercício de sua expressão escrita em português e algumas características de seus erros na sua lingua-alvo):

Não conheço nada dos aspectos teóricos, mas está claro que, cada vez que se relaciona com alguém, você continuamente negocia com esta pessoa a sua identidade e a identidade dela naquele específico relacionamento. Sempre fui muito sensível, instintivamente, a esse aspecto da relação com as pessoas - às vezes, percebe-se tão claramente qual papel uma pessoa está (esteja?) pedindo para você representar e qual quer (queira?) assumir com você... Uma relação é clara, pelo que me concerne (PER QUEL CHE MI RIGUARDA), quando você entende o que está pedindo ao outro e o que o outro está pedindo a você, e ambos (os dois?) se comportam de conseqüencia - apesar de as situações serem geralmente cheias de facetes, que sempre é muito difícil (e quase nunca necessário) esplicitar. [L.E-MAIL I: 08/09/2004]

Víamos, no jogo de identidades, motivo de diversão e, ao mesmo tempo, instruçâo - aprender língua e cultura estrangeiras brincando. Este "brincar de acreditar" que o outro "seja" o personagem que deseja representar é, sobretudo, intuitivo e com sensibilidade às intençôes do parceiro. Não posso dizer, entretanto, que isso foi reciproco, pelo menos de minha parte, mas posso notar no discurso de Luisa, abaixo, essa questão lúdica e sua disposição de "jogar o jogo":

Você me procurou por ser italiana e eu lhe pedi aulas de português. Então estava muito claro, no começo, que o nosso papel era em primeiro lugar um papel de representação nacional. (minha ênfase) Não só fizemonos perguntas sobre os respectivos paises, sua lingua e sua cultura, mas 
também olhamos um à (para a?) atitude do outro à procura dessas quimeras que são a brasilianidade e a italianidade. (minha ênfase) Empenhada no meu papel de professora tandêmica dedicada, vasculei [vaculhei] na minha pessoa todas as migalhas possiveis de italianidade; achei isso divertido e instrutivo. Falei em italiano com você quanto mais possivel (IL PIU POSSIBILE), tentando esquecer que estava falando com um estrangeiro, ao perceber que era isso que você queria. (minha ênfase) [L.E-MAIL I: 08/09/2004]

Este jogo de acreditar não era estático, mas dinâmico, em constantes fluxos, conforme o jogo de aprendizagem de lingua estrangeira se desenvolvia. No segmento e uma mensagem de e-mail, abaixo, Luisa trata das transformaçôes do seu papel de parceira de Tandem. O inicio, o papel de Luisa éo de "representação nacional" para se tornar, ao longo do processo, o de "representação de um ser humano", sem barreiras culturais ou lingüisticas, mas "uma amostra vivente de italianidade".

(...) Fiquei (estive?) intrigada (INCURIOSITA) com o seu desejo de aprender o meu idioma e a sua necessidade de se espressar nele; de italiana passei a ser uma italiana interessada ao que você tinha a dizer (AVEVI DA DIRE), depois uma italiana que gosta de você e, no período de úteros e hospitais, uma italiana que precisa da sua ajuda. Parece aquela história do Petit Prince, que conta, em termos bem comportamentistas, a origem (o nascimento?) de uma amizade. Agora que poderia achar que me tornei simplesmente uma amiga italiana, a coisa interessante é que a italianidade me incomoda um pouco. (minha ênfase) Depois de você passar tanto tempo e demonstrar tanta vontade de me falar (preferivelmente em italiano, mas não sempre, o que também tem a sua importância) de si mesmo, de seus interesses, dos seus problemas, das suas curiosidades, da sua familha, da sua psicanalista e do seu passado, tanto carinho em me perguntar sobre o meu maldito intestino e outras coisas, acho difícil recuperar a minha italianidade e colocá-la ao centro do nosso relacionamento. Não estou falando do meu papel de dicionário vivente, nem do meu papel de falante italiana, que continuam sendo os mesmos, mas do papel de amostra vivente de italianidade, qualquer sentido isso possa ter (QUALSIASI COSA VOGLIA DIRE). (minha ênfase) [L.E-MAIL I: 08/09/2004]

Esta "amostra vivente de italianidade" é constantemente evidenciada em situaçôes sociais que convivi com Luisa fora do contexto do tandem. Por meio de Luisa, a Itália se mostrava presente em pequenas situaçôes, como a de tomar um café expresso em um bar, na qual Luisa apresentava uma pequena manifestação de sua italianidade quando pedia o seu café "curto" (uma pequena quantidade 
de café, muito forte) e não longo, como fazemos no Brasil. Quando eu explicitava tal evidência, ao explicar à garçonete que, pelo fato de ser "italiana", Luisa desejava apenas uma porção infima de café expresso em sua xicara, pois este era um modo muito freqüente de se beber café na Itália, Luisa se mostrava quase incomodada em ostentar tal representação. A continuação do segmento anterior de mensagem de e-mail, abaixo, evidencia este tal "incômodo":

(...) Tudo isso explica porque terei impulsos omicidas se você tentar mais uma vez de explicar à moça do bar como eu quero o café, sem ter em conta que poderia ter vontade de bebê-lo lungo ou de qualquer outra forma. Suponho que isso demonstre também que a italianidade é um conceito mais complicado e contemporaneamente muito mais superficial de que eu pensasse há alguns meses atrás!

Quando tiver tempo pode corrigir este texto?:-)

Un ciao mezzo addormentato - Luisa che oggi ha bevuto troppo tè al bergamotto

[L.E-MAIL I: 08/09/2004]

Para Luisa, como ela própria salienta no seu relato, italianidade é, pois, um conceito muito mais complicado que, naqueles momentos, eu o transformava em algo quase banal. Luisa questiona meu impulso esteriotipante - italianos bebem o café expresso "corto", ao questionar, ou mesmo dizendo que, talvez, pudesse querer o seu cafe" "lungo". (J.INTERIM II.)

\subsection{Suspender as regras do jogo. Tandem como espaço extra- cultural. História de Luisa}

Sobre o assunto dos papéis nacionais assumidos pelas pessoas, que leva ao tema e ao perigo dos estereótipos, já estava refletindo antes de começarmos o tandem, como testemunha este trecho de um texto por mim escrito nos primeiros momentos do tandem:

Eu prometi que escreveria acerca de imagens idealizadas dos países. Esse é um enigma que me parece atravessar toda a minha vida. Aqui no Brasil só mudou de perspectiva. Deparo-me, aqui, com a Itália imaginada pelos brasileiros, pelos descendentes de italianos, pelos simpatizantes, pelos alunos dedicados e pelos não dedicados (para os quais o "italiano" só é uma disciplina escolar). Na minha perspectiva, eles todos olham para mim (uma "italiana nativa" enviada aqui pelo governo italiano para representar o meu país em uma universidade estrangeira, quase "um panda no zoológico") sem me ver; eles vêem, 
no meu lugar, uma imagem que faz sentido para eles, algo que tem a ver com as coisas que eles procuram, que eles desejam, que eles gostariam de ser ou ter, que os pais deles têm experimentado no período da imigração italiana. De vez em quando, as pessoas falam comigo da língua italiana ou da Itália com aquele ar estático que no passado eu reservei para a Alemanha, ou para a Turquia, países que eu muito amei (e idealizei) e que poderia, agora, usar com o Japão, se já não fosse safada demais para jogar esse jogo seriamente. Ou seja, eu entendo isso, não posso criticar. A gente estudou, já sabe que estereótipos também têm a sua função, já sabe que identidade é uma coisa não absoluta, dependente de relacionamentos, et cetera et cetera, mas mesmo assim... eu sinto um mal-estar forte em relação a isso. (L. ANEXOI, 2)

Por isso, devido às reservas que já mantinha a respeito, durante o Tandem muitas vezes tratei este aspecto de identidade ironicamente. Por outro lado, eu também cheguei a tentar associar minha identidade à lingua que aprendia, procurando "minha brasilidade":

Un po' per gioco un po' sul serio, io voglio sentirmi più brasiliana (minha ênfase) e lui vuole sentirsi più italiano. Che significato diamo a questi aggettivi nazionali, non è affatto chiaro. Lui sembra associare l'italianità alla capacità di esprimere sentimenti forti, soprattutto di rabbia, ma in un modo reso accettabile e carino dalla lingua straniera; per contrasto, mi viene in mente quella sua eterna gentilezza, che a volte sembra una impossibilità di accettare la rabbia e uno sforzo voluto di costruirsi impedendosi sfoghi e colori forti. Cerchiamo tutti un'altra versione di noi stessi, in un'altra lingua? Io sicuramente ne cerco una socialmente più competente, desidero essere più cortese e più rispettosa delle regole sociali qui di quanto sia stata in Italia o in Turchia. Per questo nel portoghese del Brasile voglio vedere la gentilezza e l'ironia, la capacità di controllarsi, cioè esattamente l'opposto di quello che il mio compagno di tandem vuole vedere nella mia lingua (minha ênfase). Così io parlando con lui mi controllo al massimo grado, e insisto spessissimo su quanto il controllo sia importante, in tutte le situazioni; lui sembra andare in cerca delle parole emotive, dei colori forti. (L.TEXTO NÃO ENVIADO I, "PAROLE CHIAVE")

É interessante, porém, o fato de que o interesse etnográfico e a nossa comum concepção de "cultura" em termos antropológicos, associados ao contexto específico do Tandem, foram elementos que nos ajudaram a cimentar o nosso Tandem, ultrapassando as diferenças pessoais que, em outras circunstâncias, poderiam nos afastar um do outro: 
Dal punto di vista personale J ed io siamo infatti due persone molto diverse (elemento su cui io ho sempre scherzato molto e che sicuramente ho sempre voluto accentuare (...). Al primo impatto, quando ci siamo conosciuti, senza trovarci antipatici (suppongo) ci siamo trovati però reciprocamente molto strani. (...) Probabilmente questa sensazione di "stranezza" non ci avrebbe permesso di avere una relazione di amicizia (quale quella attualmente instauratasi, sebbene un po' faticosamente), senza l'elemento di sblocco determinato dal Tandem. Di conseguenza è normale che esso continui ad essere presente anche fuori dallo spazio della lezione. Laspetto interessante, però, è il fatto che la sensazione di stranezza sia stata totalmente funzionale agli scopi che abbiamo dato al tandem, in particolare quello interculturale. E' come se il riconoscimento, nell'altra persona, di una una funzione di mediazione culturale avesse permesso di sfruttare e rendere utile la sua alterità: la differenza tra due persone e il suo significato sono completamente condizionati dal contesto (minha ênfase). Alterità e intento didattico hanno creato, nel nostro caso, uno spazio di apprendimento che non può fare a meno di una miscela tra tra realismo e stilizzazione che è un po', mi pare, il "marchio registrato" del nostro Tandem (L. INTERIM II, 1, p. 8)

A mistura de realismo e de estilização, acima descrita, que eu percebia no nosso Tandem dependia provavelmente do fato de que este contexto de aprendizagem, do ponto de vista do relacionamento, obedece a regras diferentes daquelas do dia-a-dia, por exemplo no que diz respeito à polidez..$^{18} \mathrm{Na}$ vida social, corrigir a fala de um adulto é uma forma de ameaça à face dele (Brown \& Levinson, 1978), o que leva geralmente a ignorar rupturas de compreensão e erros cometidos pelos estrangeiros; em sala de aula, pelo contrário, estos são o enfoque de muitas atividades. Os parceiros de Tandem, porém, se incontram em um espaço intermédio entre a conversação do dia-a-dia e a conversação didática em sala de aula. Isso pode levar a considerá-lo como uma espécie de mundo artificial, ou espaço ritualizado, em um plano diferente daquele da realidade. Esta, pelo menos, foi a impressão que eu tive quase desde o começo, até ao ponto de falar em "espaço ritual":

\footnotetext{
${ }^{18}$ Acerca da diferença na conversação nativo-estrangeiro no Tandem e na conversação em sala de aula, em termos de análise da conversação, veja-se Rost-Roth, 1995. Ho provato a fare un elenco approssimativo: ...[segue lista de acerca de 50 pessoas]
} 
Intanto si sono scanditi i primi rituali.

(...)

Questi rituali sono importanti perchè separano lo spazio della lezione (non diversamente da quanto accade a scuola, in realtà) dal continuum della vita normale (e sociale). Lo incorniciano, come dicono i sociologi del turismo (deve essere un termine semiotico, devo cercarlo meglio), separandolo dal resto e dandogli così rilievo e un significato speciale. Cfr anche metafore, sotto.

Ogni elemento che buttiamo in questo spazio rituale, dove tu costruisci un'identità e io faccio le mie esplorazioni, è una specie di mattone, che può essere accettare, scartato, riutilizzato, accantonato temporaneamente o modificato. Si tratta di parole, concetti, elementi culturali o geografici, ricordi personali, ma anche di persone. Tutte le cose e le persone che vengono citate sono materiali per la costruzione (e da questo punto di vista, tra l'altro, è interessante anche quello che NON viene citato). Per esempio, tu hai mostrato una specie di bisogno di parlare ripetutamente delle persone della tua famiglia legati all'Italia. Io so che è importante parlarne proprio con me perchè in questo spazio io sono l'Italia. Buttarli sul piatto qui li legittima, li autentica, li fa esistere nella costruzione della tua identità italiana. (E' lo stesso motivo per cui io avevo tanto bisogno di parlare delle cose che ho visto in Giappone con E. o M. o N. [conhecidas de orígem japonesa], per cui chiunque sia andato in un paese VUOLE raccontare minuziosamente, nei dettagli, a una persona DI quel paese, tutto il suo viaggio e quello che ha fatto, perchè solo così quegli elementi diventano "autentici", si oggettivano, cominciano ad esistere davvero).

Delimitato uno spazio comune, l'abbiamo progressivamente ammobiliato e vivificato attraverso i nostri discorsi, evocando cose, persone, esperienze, mettendole in gioco e in comune. Il numero di persone che abbiamo evocato, anche solo semplicemente citandole, nel giro di dodici volte (nove Tandem e tre incontri extra) è veramente grande!

(...)

Fuori dal Tandem, è come se si uscisse da uno spazio semplificato. (...) $\mathrm{Ci}$ si è visti anche alcune volte fuori dalla lezione di Tandem:

- con la tua famiglia (è interessante che tu mi abbia invitato per il venerdì santo, per la festa della mamma... tutte feste che hanno un carattere spiccatamente familiare, e infatti l'Italia per te rappresenta le radici)

- nel tuo ambiente di lavoro (che la presenza di due mie allieve porta ad intersecarsi con il tuo, anche questo è interessante).

(...) 
Il Tandem è uno spazio concentrato di ascolto reciproco; fuori, invece, le coordinate e l'atteggiamento sono, come è ovvio, completamente diversi. E' un po' come se si dovesse rifare tutto da capo: ci si ritrova a fare i conti con il "mondo reale", il mondo concreto, che invece si esclude o si incornicia, quando si fa la lezione di Tandem. (L.ANEXOI, 20, p. 2-5)

De fato, quando, durante o Tandem, comecei a refletir sobre este tema, tive a impressão de que, neste mundo por nós construido, não valessem todas as regras da vida real, mas só a quelas implicitamente negociadas por nós.

Il portoghese così diventa anche la lingua delle confidenze, qualcosa di ancora più strano perchè sono le confidenze di uno sconosciuto, che tale rimane anche dopo averle fatte. Ho la sensazione di essere risucchiata come sul palcoscenico di un teatro, e di essere costretta, volente o nolente, a prendere parte alla rappresentazione, una rappresentazione che è veritiera ma nel frattempo è anche totalmente metaforica. Questa impressione è ancora rafforzata dalla continua vigilanza linguistica che devo assumere mentre parlo e ascolto, durante la lezione. Questo atteggiamento doppio di professora e confidente mi stupisce, soprattutto perchè in qualche modo è completamente impersonale. Non so se siamo amici: siamo molto più colleghi in un'impresa, compagni di gioco,compagni di squadra. E' una situazione così totalmente lontana dalla vita normale, così costruita e controllata che è affascinante per la sua alienità. (L.TEXTO NÃO ENVIADO $I$, "PAROLE CHIAVE")

Alguém poderia ver talvez em um espaço como aquele do Tandem, onde se cruzam diferentes culturas com o mesmo status (garantido pela regra de reciprocidade do Tandem), como um tipico espaço de contato (Pratt,1992), onde não valem todas as regras de uma cultura, mas só algumas, aquelas escolhidas e negociadas pelos participantes; ou como um terceiro espaço, no sentido no qual foi utilizado por Kramsch (1998). Neste espaço, a cultura de cada um de nós, a nossa identidade social e pessoas eram como suspensas, colocadas entre aspas; 0 tandem foi para nós um espaço onde muitas vezes se falava em culturas em lugar de fazê-las agir diretamente. Isto pode explicar o fato de que se transformou em uma ocasiāo propícia para ousar colocar em discussão nossas próprias identidades sem ter medo. (L.INTERIM III)

\subsection{A relação com o outro. História de João e Luisa}

Neste espaço de aprendizagem, brincadeiras, teatro, rituais, troca de informaçōes e construção de sentidos, nosso Tandem criou um relacionamento pessoal. 
Quase não nos conhecíamos, inicialmente: tivéramos pouquissimos contatos, antes de começar. Durante o Tandem, chegamos gradualmente a um conhecimento reciproco, por meio de narrativas de vida, cautas perguntas $e$ explicaçôes, caracterizadas pelo respeito e por um grande cuidado.

Como se deu este relacionamento pessoal, neste especifico contexto?

Durante o tandem, Luisa tentou definir nossas regras implicitas, por ela percebidas da seguinte forma (e parcialmente aceita por João):

- Non si fanno domande su argomenti personali in quanto tali, a meno che non sia l'altro stesso ad introdurre l'argomento.

- Non si rifiuta nessun argomento (si ascolta tutto quello che l'altro dice e si cerca di rilanciarlo).

- La conversazione ha come scopo un incremento di conoscenze sul proprio paese e sul paese dell'altro; qualsiasi argomento proposto viene considerato e trattato soprattutto in quest'ottica. Ciò implica:

- l'accettazione di una posizione peculiare, quella di mediatore culturale, che è preminente sull'identità personale.

- l'accettazione senza reazioni negative di qualsiasi punto di vista espresso dall'altro sul proprio paese

- il massimo sforzo per formulare ogni informazione in chiave "antropologica", cioè dal punto di vista dello straniero (...).

- si va con i piedi di piombo (avendo assunto un punto di vista "antropologico" sull'altro, si presuppone che praticamente qualsiasi cosa possa essere tabù o comunque avere differenti o sgradevoli implicazioni per l'altro)

- si va a caccia delle differenze, più che delle somiglianze.

- Si riformula anche sul proprio versante (cioè sul versante della propria cultura di origine) qualsiasi spunto offerto dall'altro. (L.ANEXO 20, I, p. 1-2)

Mantivemos um equilíbrio entre a polidez, que levava à tendência a não fazer perguntas diretas, e o interesse pessoal junto com a oportunidade didática, que levavam a retomar os assuntos oferecidos pelo parceiro. Tais assuntos foram vários:

(...) Si sono anche delineati una serie di argomenti di comune interesse (antropologico-linguistico-didattico-metariflessivo): 
- la visione del proprio paese da parte degli stranieri

- confrontare il punto di vista nativo con quello dello straniero

- lingua come mezzo di espressione di cultura e di identità

- didattica

- riflettere su quello che stiamo facendo, su cosa, come e perchè impariamo

(L.ANEXO $I, 20$, p. 1-2)

Este nosso viés pode ser definido etnográfico não tanto pelos assuntos em si, mas sim, principalmente, pela maneira de tratá-los, sempre checando a brasilidade ou a italianidade do que dizíamos. Um papel de representação nacional, aliás, é implícito na própria natureza do Tandem: se dois "nativos" estiverem se encontrando e aprendendo um a lingua do outro, é provavelmente normal que eles se vejam, antes de mais nada, como uma italiana e um brasileiro. (L. INTERIM III) Ambos, no entanto, compartilhávamos um profundo interesse a respeito. Portanto, o mesmo elemento de representação acima já citado ${ }^{19}$ que algumas vezes despertou as protestas de Luisa ou se manifestou de forma quase teatral, ou ritual, outras vezes foi levado seriamente.

Apesar desta vertente etnográfica, o próprio relacionamento pessoal foi o aspecto que Luisa achou logo o mais marcante da aprendizagem in-tandem. ${ }^{20}$

Diferenças pessoais haviam-se evidenciado já quando haviamos nos encontrado pela primeira vez, quando o Tandem foi proposto por João (estando ainda no início do seu processo de obtenção da cidadania) e Luisa estava no primeiro mês de sua permanência no Brasil. Naquela época, constituíram um obstáculo. Conforme Luisa escreveu:

Me lembrei, assim, da primeira proposta de Tandem que tinha recebido, nos primeiros dias da minha chegada, por um colega entusiasta e esquisito, que queria trocar seu conhecimento do português com meu conhecimento do italiano (liçôes particulares, tinha

\footnotetext{
${ }^{19}$ Conforme o relato de João, acima (2.6, L.E-MAIL I: 08/09/2004,p. 23).

${ }^{20}$ Conforme sua análise (VASSALLO, 2006), também as mudanças que aconteceram no seu estilo de ensino, atribuíveis ao tandem, foram relacionadas com uma maior importância dada ao elemento pessoal no ensino. Ver também, ibidem, a tabela de brincadeira que ela construiu acerca das nossas diferenças, além da descrição que ela deu de João já na primeira tarefa de casa.
} 
pensado eu), em um momento no qual eu não tinha absolutamente cabeza ou tempo para isso, porque estava empenhada em aprender o meu novo trabalho, em montar a minha casa e em me recuperar da confusão terrível de estar vivendo em um país estrangeiro. Aquele colega, João, também não tinha me parecido muito confiável, por pequenos pormenores importantes para uma estrangeira recémchegada, que só dispóe de sinais indiretos para avaliar as pessoas: uma promessa distraidamente feita (...), não colocada em prática; uma evidente e aliás compreensível dificuldade a entender meus problemas (...); e uma maneira de socializar tão informal e tão direta que eu, não acostumada com o Brasil, simplesmente não conseguia entendê-la (minha ênfase). (L.POSTINTERIM, II, 7, p. 6)

Ao desenvolvermos o Tandem, dois anos e meio depois, chegamos também a discutir sobre este primeiro desencontro, no qual João também admitiu ter recebido impressóes negativas acerca de Luisa. Durante o Tandem, porém, conseguimos negociar outras formas de auto-apresentação, mais positivas, $e$ acabamos interagindo bem:

DE LUISA PARA JOAO, lunedì 20 settembre 20041.10

güle güle (= sorridendo sorridendo, cioè arrivederci)

Parli sempre dell'importanza degli amici... pare che tu te ne sia definitivamente guadagnata una (anche se è un po' buffa e strampalata e dà gli spintoni per correggere gli errori). (L.E-MAIL, I, 20/9/2004)

DE JOAO PARA LUISA, lunedì 20 settembre 20046.47

Re: güle güle (= sorridendo sorridendo, cioè arrivederci)

Anche a me è molto divertente fare qualsiasi cose con te. Hai un amico. (L.E-MAIL, $I, 20 / 9 / 2004$ )

Qual o papel do relacionamento pessoal no nosso Tandem, em relação com os aspectos didáticos?

Certa vez, em uma tarefa de casa, Luisa descreveu nossa maneira de proceder como um "esforço de manter um equilíbrio entre a relação pessoal e aquela didática" (L.ANEXO, I, 20, p. 2). Pondo o relacionamento pessoal no último lugar, chegou a listar em ordem decrescente os papeis que desempenhávamos: "em primeiro lugar de mediadores culturais, em segundo lugar de docentes e de aprendizes e finalmente de pessoas" (L.ANEXO, I, 20, p. 3). João não concordou e comentou que não considerava possivel estabelecer uma ordem de importância dentre esses elementos, aliás difíceis de ser separados. Ao longo do tempo, Luisa acabou mudando de idéia. De fato, por um lado, notou que ela própria, em uma 
anotação diarística, havia apontado quase para uma prioridade do conhecimento pessoal, descrevendo implicitamente o Tandem como baseado antes de mais nada no relacionamento:

27 maggio: grammatica e registratore. Per me è stata la prima volta che mi sono sentita del tutto a mio agio con Joao. Nel senso che finalmente mi pareva di avere inquadrato con esattezza la situazione (e la persona). Che avessi finito la parte conoscitiva. Per questo mi è sembrato che ora potessimo cominciare con la grammatica. (L.ANEXO, $I$, TEXTO NĀO ENVIADO4. APPUNTI DOPO UNA UNA LEZIONE)

Por outro lado, se deu conta de que os nossos relatos acerca dos elementos didaticamente eficazes do Tandem apontavam quase todos para aspectos pessoais. Por exemplo, em um texto de João:

Non posso pensare sull'una sola cosa, ma in tante caratteristiche dell'atteggiamento di Luisa che mi fanno imparare italiano di più. (...) Inoltre, c'è suo atteggiamento d'interesse a tutto quello che parlo. Quest'interesse è reciproco, non soltanto perché abbiamo quasi la stessa età, ma per il semplice fatto de che noi siamo interessati in quello che il altro pensa. In questo Tandem, non impariamo soltanto italiano e portoghese, ma scambiamo idee e prospettive culturali. Come Luisa ha detto prima, non giudicammo i pensieri dell'altro, ma li sentiamo con il cuore aperto, pronti a riflettere sulle sue diverse faccette. (...)

.Il Tandem è un luogo d'interazione, dove facciamo un equilibrio fra contenuto e forma per capire quello che il altro pensa, quella visione di mondo che il altro apporta de la sua cultura e chi i due vogliono vederla capita sulla prospettiva dell'altro. Quest'atteggiamento non può essere cercato d'una sola parte, ma d'ambedue. (J.ANEXO, $I, 10$, p. 1)

\section{Também, em um texto de Luisa:}

9 giugno- Atteggiamenti di joão che mi spingono ad imparare

- Il fatto che mi interessi quello che ha da dire // che dica delle cose che mi interessano (sembra uguale, ma non lo è affatto. Non saprei dire quale delle due espressioni sia più adeguata)

- (e, di fatto, J. quasi mai dice quello che mi aspetterei, o che direi io. Però difficilmente dice cose che non mi interessino. La combinazione delle due cose mi porta ad ascoltare con attenzione quello che dice, anche quando sono in disaccordissimo. Elemento di motivazione piuttosto forte.)

(...) 
- Il fatto che per molte cose sembri essermi complementare. (L.ANEXO , I, 17 p. 1-3)

- Entusiasmo (...),disponibilidade a se colocar em jogo pessoalmente (às vezes) a ouvir (...), a falta de medo (...), a disponibilidade a aceitar as críticas (...), o respeito para o outro (...), il fatto che abbia un modo di fare in cui mi riconosco (...), il fatto che abbia una concezione della lingua simile alla mia (...), il fatto che accetta alcune delle cose che gli passo e le rielabora (...) (L.ANEXO, I, 17 p. 1-3).

Desta forma, Luisa concluiu que, na aprendizagem in-tandem, talvez seja importante não o tipo de relacionamento mas o fato em si de se construir uma relação em língua materna e estrangeira.

Houve também o movimento contrário: elementos do Tandem que desbordaram na relação pessoal fora do Tandem, como apontado neste excerto de João:

Sinto-me confortável ao falar italiano, principalmente quando os meus interlocutores são nativos e não falam o português. Luisa é a exceção - fala muito bem o português, quase três vezes mais do que eu falo italiano; entretanto, não me sinto inseguro para falar com ela, porque sua atitude é extremamente construtiva.

Além disso, existe algo nesta sua atitude que se assemelha a um "acolhimento da língua e da cultura italiana", algo mediador e, ao mesmo tempo, compartilhante que é difícil explicar, mas fácil de dar exemplos. Este acolhimento se manifesta em situaçôes sociais em português, quando estamos em interação com brasileiros e, em italiano, quando estamos entre pessoas que falam italiano. Quando dentre pessoas interagindo em português, este acolhimento se manifesta em "apartes em italiano" - Luisa se volta para mim, "em off", como se retirando da interação em português, e faz apartes em língua italiana rapidíssimos (que, às vezes, se torna dificílimo para que eu a compreenda, mas me esforço ao máximo). O efeito de tal comportamento é o de "acolhimento à língua e cultura italianas", como se ela dissesse o que tem a dizer da seguinte maneira: "Entre nós, italianos, acho que...". Outra manifestação deste tipo é quando, durante uma interação em português com brasileiros, Luisa encontra alguma falha no seu excelente português e vira-se para mim, perguntando, em italiano, como se diz tal coisa em português, como se eu fosse um nativo da língua italiana e soubesse como solucionar o seu problema de comunicação em um zás - trás. Por outro lado, quando estamos interagindo em italiano, dentre pessoas que falam italiano, tenho a sensação que Luisa é minha aliada: faz interrupçōes no assunto para explicar-me alguma estrutura ou vocabulário os quais ela sabe que desconheço, facilita acesso a questões culturais italianas específicas, etc. 
Enfim, sabendo de minhas intençôes de "entrar na cultura italiana", Luisa medeia as situações difíceis, facilita os acessos, diminui os percalços, atua como fonte de informaçôes de fácil e imediato acesso. Logicamente, esta sua "prontidão" como mediadora e facilitadora da entrada na cultura e língua italianas, contribui imensamente para a minha agenda de construção de uma identidade italiana e de sua cidadania. (J.TEXTOS INTERIM, II).

A relação pessoal, em suma, entrecruzou todos os aspectos do nosso tandem.

\section{Tandem e identidade}

Quais histórias escolhemos viver, na época do tandem e agora, por meio desta pesquisa?

Há uma história de João querendo obter uma cidadania italiana como forma de herança simbólica recebida por uma família quase desaparecida; desenvolvendo, por isso, uma construção arqueológica de identidade, pela coleta de documentos; se deparando com a natureza de araque da cidadania enfim recebida e decidindo fazer um tandem para tornar essa cidadania verdadeira. É uma história povoada de antepassados e de documentos, salpicada de nomes e datas (e fotografias, que foram mostradas repetidas vezes no tandem); subentende desejos concretos e simbólicos, é burocrática e afetiva ao mesmo tempo, animada por repetidos movimentos de vai e vem entre países e séculos. Há uma outra história de João conseguindo ter cada vez mais segurança em italiano, pelo tandem, adquirindo cada vez maior profundidade no conhecimento da língua e da cultura desejada, viajando a Itália e se relacionando com outros italianos. Há uma história de João se interrogando sobre o tandem, sob instigação de Luisa.

Há outras histórias de João que apareceram de esguelha no tandem. São histórias de João aprendiz de outras línguas, gostando de aprender falando e brincando de ator em língua estrangeira, promotor de outros tandems em outros países; de João em outras épocas e com outras pessoas, de João ator, de João bailarino, de João sobrinho, de João tio, de João parceiro, de João professor, com todas suas aulas, suas pesquisas, seus alunos, seus artigos, seus interesses; de João se relacionando com outras pessoas.

Durante o tandem, todas essas histórias permaneceram como pano de fundo da história principal.

Há mais histórias, posteriores ao tandem, que foram se misturando com as anteriores: histórias futuras de volta ao Brasil e visitas para Itália, de pesquisa 
junto, de João e de Luisa desenvolvendo outras formas de Tandem a distância, para estendê-las também a alunos que não podem viajar por meio de novos projetos. Após o tandem, todas essas histórias se misturaram.

Há uma história de Luisa aventureira, mudando da Itália ao Brasil e criando para si mesma novas histórias de mudança, uma mudança tão grande que o Brasil pareceu apagar a Itália na sua vida; uma história de Luisa se deparando com dificuldades tão grandes em entender a Itália dos outros aquela dos brasileiros e dos descendentes - e em compará-la com a sua, que não conseguia expressá-las, por falta de palavras. Há uma história de Luisa sendo aceita sem ser acadêmica pelo meio acadêmico aonde foi trabalhar, se sentindo porém uma sem-pesquisa e professora de italiano de araque; portanto, desenvolvendo um mestrado italiano pela Internet, abrindo horizontes e descobrindo a didática. Há uma história de Luisa se deparando com o fato de não ter ninguém no Brasil para conversar de ensino/aprendizagem e sofrendo por isso; querendo construir sua identidade de professora de italiano para estrangeiros, depois de formadora de professores, depois de pesquisadora. Há uma história de Luisa aprendendo o português do dia-a-dia no Brasil e não querendo estudá-lo, percebendo que não precisava: uma história de descuido e porém de sucesso, de limitaçóes e de falta de ocasiões.

Outras histórias de Luisa antes de vir ao Brasil entraram de esguelha no tandem: histórias de Luisa estudando arqueologia e morando na Itália; de Luisa esposa, na Itália, na Turquia e no Brasil; de Luisa não conseguindo apresentar no Brasil e nem no tandem suas histórias da Turquia e de arqueologia, porque não eram relevantes; de Luisa viajando no Brasil e se relacionando com outras pessoas; de Luisa no Brasil estudando japonês, ao invés do português. principal.

Todas essas histórias permaneceram como pano de fundo da história

Além dessas, há histórias de balé, de teatro, de piscina, de comidas cozinhadas, de passeios, de carros quebrados e consertados, de bicicletas, de cachorros acolhidos e levados para passear; de visitantes de um parceiro acolhidos por ambos; histórias de psicanálise, histórias de supermercado, de gênero e sexualidade, de línguas faladas e comparadas, de lembranças de viagens; histórias de hospital, de doenças, de pessoas caras falecidas; de tapetes, de cafeteiras, de livros, de objetos trocados, emprestados, presenteados. Aparecem ou estão implícitas nos textos da pesquisa, entrelaçando-se com a história principal de João e de Luisa, misturando-se com o nosso dia-a-dia, tecendo uma rede sutil de pormenores evocativos, criando sentidos e estabelecendo relações. 
Todas essas histórias se transformam.

A história de João-querendo-obter-a-cidadania-italiana-como-formade-herança-simbólica se transforma na história de João encontrando-se com uma italiana-chegada-ao-Brasil-depois-de-uma-mudança-tão-grande-que-oBrasil-apagou-a-Itália, e tendo-dificuldades-tão-grandes-a-entender-a-Itáliados-outros-e-a-compará-la-com-a-sua,-que-não-conseguia-expressá-las, porfalta-de-palavras - pelo menos até ela fazer um tandem com João. Daí a história de Luisa-não-conseguindo-entender-nem-expressar-as-dificuldades se torna a história de Luisa-encontrando-e-fazendo-um-tandem-com-um-brasileirointeressado-em-ouvir-falar-dessas-dificuldades-que-não-podiam-ser-expressas; e, conseqüentemente, aparece uma nova história de Luisa procurando um caminho para expressá-las, em uma língua nova, para explicar melhor ao brasileiro. Mas daí também a história de João querendo se tornar cidadão italiano para recuperar uma italianidade ligada a pessoas amadas e a um passado secular se transforma na história de João obrigado a lidar com o desinteresse de uma italiana não muito interessada neste passado, porque justamente faz parte das suas dificuldades em entender a italianidade dos brasileiros. E pois a italiana, Luisa, brinca ironicamente de assinar por heterônimos, a história do brasileiro, João, brincando em outra língua de vestir as roupas de um personagem- o brasileiro-italiano ou italiano-brasileiro, ninguém sabe qual a ordem correta - acaba se tornando a história de João que assina ironicamente pelo seu heterônimo italiano Giovanni Antonio: já a sua história da procura da italianidade se tornou a história de João que brinca de italiano com Luisa, misturando as pessoas amadas e o passado com novas pessoas e com o presente daquela Itália que Luisa não consegue fazer perceber aos brasileiros. Por sua vez, a história de Luisa assinando por heterônimos acaba de improviso, após ser analisada e comentada por João, sendo substituída por uma nova história de Luisa, à procura de brasilidade, talvez por simetria com as histórias de João. Nessa altura, a história de Luisa se sentindo uma professora de italiano de araque e querendo aprender mais de didática, não tendo ninguém no Brasil para conversar sobre este assunto, já se tornou a história de Luisa que, aceitando fazer um tandem com um brasileiro, descobre que pode muito bem conversar com este falante de português também de didática e que João tem muita coisa a lhe ensinar - em italiano e em português, obviamente; daí a história do professor João, que nada havia a ver com a Itália, se transforma aos poucos também na história de João tentando conversar e escrever de didática em italiano, para explicar melhor seus conhecimentos à Luisa e chegando a dar 
palestras em italiano na Itália; a história de Luisa sem-pesquisa querendo ser aceita como par pelos acadêmicos se transforma na história de Luisa que começa a pesquisar o tandem com um acadêmico - em português e em italiano, obviamente; daí a história do acadêmico conhecedor de pesquisa narrativa se torna a história do professor João que quer ajudar Luisa a pesquisar o Tandem e essas histórias acabam se transformando na história de Luisa e João pesquisadores de Tandem. E esta, aliás, não é o fim da história.

Da mesma forma, a história dos conhecidos e familiares e pessoas amadas, detestadas, estimadas de João e de Luisa, e presentes nas vidas deles, se entrelaçaram todas as vezes que foram levadas à fala em uma das duas línguas do tandem; e cada vez saíram um pouco diferentes, pelo esforço do outro de achar e sugerir as palavras estrangeiras adequadas, pelo esforço de entender e responder e decidir juntos qual é o significado de todas essas histórias.

si può dire (...) che una lezione di lingua costruita intorno al raccontare se stessi, quasi ossessivamente, tutto il tempo, è un fortissimo creatore di identità. Io ho avuto la sensazione molto forte, fin dall'inizio, che noi stessimo quasi costruendoci un mondo dal nulla, a colpi di atti linguistici, e ho ritenuto questo processo interessantissimo da vedere. (L.ANEXOS I, 20, p. 1-2).

Sapere che [João] c'era mi dava una grande sicurezza, come se fosse il custode della mia personalità in Brasile e il simbolo della mia vita qui, della mia personalità qui. Forse questo effetto si raggiunge attraverso il continuo raccontarsi. L'altro diventa il depositario dei tuoi racconti, quindi in lui si cristallizza quello che tu credi di essere, che hai dichiarato di essere, che vuoi essere o che sei. (L.TEXTO NÃO ENVIADO, I, "PALAVRAS CHAVE")

A italianidade procurada por João circula em todas as histórias, mesmo aquelas que nada têm a ver; a língua que João queria aprender torna-se a forma na qual todas elas são contadas e a língua italiana torna-se uma língua para criar histórias, uma língua para criar identidade.

Ti devo dire che nel messagio scorso, ho sentito qualcosa moltissima familiare con la lingua italiana, force per il tono di scherzo di nostri messagi, anche per il livello di prossimitá a cui nostra relazione d'amicizia è arrivata. Che pensi? Questo conferma la mia tese che, per imparare una lingua straniera, uno bisogna (a meno per me) degli aspetti afetivi. In questo mio processo d'aquisizione dell'italiano questi aspetti afetivi si ripetono: non ho una giudicessa (juiza) ma una 
facilitatrice (facilitadora), ho il spazio per fare sbagli senza avere una sensazione di ridiculo, condividiamo un senso di scherzo, etc (mi sono dimenticato di come scrivere etc in italiano, sei che tu mi hai detto). (J.E-MAIL I: 9/9/2004)

E da mesma forma, a língua portuguesa que Luisa achava bom treinar para obter um certificado, mas que não era preciso saber melhor porque ela iria embora deste país, no qual ela já conseguia se virar bem no dia-a-dia, aquela língua que não era o primeiro objetivo do tandem, se torna a língua descrita por ela nesta tarefa de casa, a língua das histórias que ela criou para si mesma no exterior:

E o que acontecerá com os sons associados ao Brasil, quando eu estarei longe? De vez em quando, as vozes das algumas pessoas de aqui me enternecem pelo acento. No meio de uma conversa qualquer, ouço alguém falar com aquela típica desarmonia harmônica de vogais e de consoantes, com aquele chio da $\mathrm{R}$ do interior fazendo a frase saborosa e mais cheia de sentido, e fico pensando: "daqui à um ano e meio estarei longe de aqui e não ouvirei mais tudo isso". E fico com medo de sofrer por uma saudade incomensurável, irremediável. Este período da minha vida, que devia ser uma brincadeira, um prêmio de consolação depois de uma doença pesada, um descanso antes de decisões definitiva, poderia se tornar muito diferente: uma época na qual eu, querendo me tornar estrangeira para todo mundo, fui ao invés adotada por um pais acolhedor. E aí eu me tornaria órfā, mais uma vez. De fato, é difícil acrescentar um pais á sua bagagem mental sem perdas, é difícil amar á distancia, se descobrir mudada sem virar um pouco esquizofrênica, conseguir trazer de volta a pessoa que você se tornou no exterior, junto com móveis e livros, coisas essas muito mais tangíveis e manejáveis. Mesmo a língua é difícil de se manter, quando você não a usar. Eu sei que perderei o português. Por isso acredito que no futuro, quando eu estarei longe do Brasil, cada vez que eu ouvirei uma R chiada, uma A nasal, ou uma dessas E deslizantes, parecidas com a creme de leite que este país adora, terei uma dor intensa e me lembrarei com tristeza da maravilhosa bola de sabão na qual vivi uma vez, até ela estourar e me deixar mais pobre. (L. TEXTO 1 NÃO ENVIADO I, "LUISA 4".)

As histórias contadas durante o tandem são as histórias que contamos hoje nas nossas vidas, nas nossas duas línguas. A pesquisa narrativa e seu conceito de identidade, portanto, nos levaram a perceber a riqueza e a fluidez de nossas identidades como aprendizes de língua, no contexto de aprendizagem inTandem. 


\begin{abstract}
Narrative Inquiry (Clandinin \& Connelly, 2000) understands human experience as lived and told stories. Within this qualitative mode of research, participants tell stories and researchers retell and reconstruct them through narratives about the experiences. By having this methodological framework as the backbone of our research, we have conducted a narrative inquiry into our shared experience of in-tandem learning of Portuguese and Italian - an eight month experience of a face-to-face tandem. Within this period we experienced and collected data about our learning processes of learning each other's languages: field notes, reflexive email messages exchanged during that period and our notes during our lessons. As we relive our stories of that period by means of the narrative we present here, we want to highlight the identity elements in our tandem that we found to be related to learning. We also wish to point out the triggering elements of identity that are peculiar to this learning context.

KEY-WORDS: Narrative inquiry, in-tandem learning, identity, foreign language, face-to-face tandem.
\end{abstract}

\title{
Referências
}

BROWN, Penelope; LEVINSON, Stephen C. Politeness: some universals in language use. Cambridge: Cambridge University Press, 1978.

CONNELLY, F. Michael; CLANDININ, D. Jean. Teachers as curriculum planners. New York: Teachers College Press, 1988.

CLANDININ, D. Jean; CONNELLY, F. Michael. Teachers' professional knowledge landscapes. Toronto: OISE Press, 1995.

CLANDININ, D. Jean; CONNELLY, F. Michael. Narrative inquiry: experience and story in qualitative research. San Francisco: Jossey-Bass Company, 2000.

JOHNSON, Donna, M. Approaches to Research in Second Language Learning. New York: Longman, 1992.

KRAMSCH, Claire. Language and culture. Oxford: Oxford University Press, 1998. MANCINI, Tiziana. Sé e identità. Modelli, metodi e problemi in psicologia sociale. Roma: Carocci, 2001.

MARKUS, Hazel Rose; WURF, Elissa. The dinamic self-concept: a social psychological perspective. Annual Rreview of Psychology, 38, p. 299-377, 1987.

PRATT, Mary Louise. Imperial eyes: travel, writing and transculturation. London: Routledge, 1992.

ROST-ROTH, Martina. Sprachenlernen im direkten kontakt. Autonomes Tandem in Südtirol. Eine Fallstudie. Unter Mitarb. v. Oliver Lechlmair. Bozen: Alpha \& Beta, 1995. 
TELLES, João Antonio.; VASSALLO, Maria Luisa. Foreign language learning in-tandem: teletandem as an alternative proposal in CALLT. The Especialist, v. 27, n. 2, p. 189-212, 2006.

VASSALLO, Maria Luisa. "Pequeno Dicionário de Tandem". Teletandem News. Boletim mensal do grupo de pesquisa Teletandem Brasil: Linguas estrangeiras para todos, 1,2, setembro de 2006, p. 6-7. Disponível em: <http:// www.teletandembrasil.org/site/docs/Newsletter_Ano_I_n_2\%20final.pdf>. Acesso em: 12 nov. 2007.

VASSALLO, Maria Luisa; TELLES, João A.. Foreign language learning intandem: theoretical principles and research perspectives. The Especialist, v. 27, p. 29-56, 2006.

Recebido em abril 2008. Aprovado em maio 2008. 